\title{
Design of an Information Technology Undergraduate Program to Produce IT Versatilists
}

\author{
Alex Koohang, Liz Riley, Terry Smith, and Kevin Floyd \\ Macon State College, Macon, Georgia, USA
}

\section{alex.koohang@MaconState.edu; liz.riley@MaconState.edu; terry.smith1@MaconState.edu; kevin.floyd@MaconState.edu \\ Executive Summary}

This paper attempts to present a model for designing an IT undergraduate program that is based on the recommendations of the Association for Computer Machinery/ Institute of Electrical and Electronics Engineers - Information Technology (ACM/IEEE - IT) Curriculum Model. The main intent is to use the ACM/IEEE - IT Curriculum Model's recommendations as a guide to design an IT curriculum that includes the IT knowledge core, general requirements beyond the IT knowledge core, and advanced courses. In addition, the recommendations are used to ensure quality standards of the curriculum. In the process, the model takes advantage of ACM/IEEE - IT Curriculum Model's recommendations to design an undergraduate IT program that produces IT versatilists.

Morello (2005) stated that IT professionals are no longer referred to as specialists or generalists. In today's business world, these professionals are IT versatilists. They not only have technical abilities, but they also possess expertise in multiple domains within organizations. Versatility of IT professionals plays an important role in today's organizations for achieving competitive tasks.

The model consists of two phases. Phase I encompasses the design of the framework for the IT program. It includes four components: formulating program mission, considering program accreditation, establishing program career goals, and establishing program competencies. Phase II focuses on the design of specific courses in the curriculum and includes the designing the IT foundational courses and the designing the advanced IT courses. It supports the foundational work of Phase I. Phase II takes advantage of putting together a curriculum that produces IT versatilists. It includes the body of knowledge and the general requirements. It also includes advanced courses within and beyond the IT domain to provide strength to the curriculum.

This paper begins with introductory remarks that include an explanation of IT versatilists and the purpose of the paper. A review of the literature about the IT curriculum is presented following a brief discussion of the ACM/IEEE - IT Curriculum Model 2008. Next, the model is presented. It describes the design of an undergraduate IT program based on the ACM/IEEE - IT Curriculum

Material published as part of this publication, either on-line or in print, is copyrighted by the Informing Science Institute. Permission to make digital or paper copy of part or all of these works for personal or classroom use is granted without fee provided that the copies are not made or distributed for profit or commercial advantage AND that copies 1) bear this notice in full and 2) give the full citation on the first page. It is permissible to abstract these works so long as credit is given. To copy in all other cases or to republish or to post on a server or to redistribute to lists requires specific permission and payment of a fee. Contact 0HPublisher@InformingScience.org to request redistribution permission.
Model's recommendations. The model uses the undergraduate IT program at Macon States' School of Information Technology as an example. Conclusion and recommendations complete the paper.

Keywords: Information Technology Curriculum, ACM/IEEE - IT Curriculum Model, IT Program Design, ABETCAC, Accreditation, IT Versatilists 


\section{Introduction}

Today's environment of rapid change in technology can significantly impact IT programs and IT graduates that are produced by these programs. Morello (2005) asserted that IT professionals are no longer "specialists" or "generalists". "Versatility" will be crucial to performing competitive tasks.

IT specialists are people with generally "deep technical skills and narrow scope, giving them expertise that is recognized by peers, but it is seldom known outside their immediate domains." Generalists are those who posses "broad scope and comparatively shallow skills" with ability to respond to situations quickly. The responses from generalists are not always thorough (Morello, 2005).

Versatilists, in contrast, are a combination of the best of both the generalist and the specialist. Versatilists have a depth of knowledge combined with an understanding beyond one specialized area. They understand many different aspects of IT as well as how their specialized area fits into IT as a whole. They also recognize how IT supports other domains in an organization. IT versatilists synthesize knowledge and context in order to respond rapidly to forces, changes, and opportunities. They "apply depth of skill to a rich scope of situations and experiences, building new alliances, perspectives, competencies and roles" (Morello, 2005).

The term IT versatilist was coined by the Gartner Research Group in 2005 (Morello, 2005). The Gartner group states that the expertise of an IT professional must include multiple domains and that technical ability by itself will not be sufficient. Today's IT Professionals hold various roles, assignments, and experiences that create synthesized knowledge and context to increase business value (Morello, 2005).

How can then a college/university IT program produce graduates that are versatilists? The purpose of this paper is to present a model for designing an IT undergraduate program based on the recommendations made by the Association for Computer Machinery/ Institute of Electrical and Electronics Engineers - Information Technology (ACM/IEEE - IT) Curriculum Model. The model applies the ACM/IEEE - IT Curriculum Model's recommendations to design an IT program that produces IT versatilists. The model consists of two phases. Phase I includes the design of the IT program framework that pays attention to the criteria set aside by Accreditation Board for Engineering \& Technology (ABET) - Computing Accreditation Commission (CAC) for accrediting IT programs. Phase II presents the design of courses in the curriculum.

\section{IT Program Design - A Brief Review of Literature}

Drinka and Yen (2008) state that curriculum design and redesign is a continuous process. Quality control measures, assessment analysis, feedback mechanisms, and continuous improvement are, in fact, critical to successful IT programs and IT curriculums. Simultaneously, business models, business needs, and technology are constantly changing. The graduates of the program must embrace life-long learning (Annabi \& McGann, 2008). This means that in addition to mastering the subject matter content, the graduates of the program must have the ability to constantly learn new material, thus embracing a career of life-long learning.

Brewer, Harriger, \& Medonca (2006) believe that the curriculum model should be used as a foundation and standard to customize a sound curriculum that is designed based on the needs and requirements of a certain curriculum. The authors further believe that the curriculum should be responsive to the local and regional needs and it must be able to adapt constantly to the everchanging environment.

Woratschek \& Lenox (2009) assert that an IT curriculum must prepare graduates to be responsible for hardware/software selection and integration into the enterprise. Examples of these respon- 
sibilities include: the installation and administration of networks, web development, multimedia, the installation of communication technologies, and management of the technology infrastructure.

Lunt, Lawson, Goodman, \& Helps (2002) conducted an exercise designed to identify the topics that should be included in an IT curriculum. Representatives from 15 universities and three professional organizations participated in the exercise. The result was a list of core courses that included network administration, software development, database administration, Web development, digital communications, data security/privacy, systems design, human computer interaction, and user advocacy. The authors further asserted that courses offered beyond the core must also be representative of the needs of employers because the employers in the area create the demand for graduates of the program and their needs must be taken into account as curriculum is developed.

Downey, McMurtrey, and Zeltmann (2008) developed a more specific list of competencies or skills in which graduates need to be IT proficient. The core courses and courses offered beyond the core include database design and administration, operating systems, web design and development, ecommerce technologies, Standard Query Language, and computing languages. Soft skills

or attributes to be emphasized in the curriculum included problem solving, critical thinking, creative thinking, oral \& written communications, and team skills.

\section{The ACM/IEEE - IT Curriculum Model}

The ACM/IEEE - IT Curriculum Model is a set of criteria intended as a guide for institutions of higher education to create and/or revise four-year IT programs. The recent ACM/IEEE - IT Curriculum Model states that as an academic discipline, Information Technology "is concerned with issues related to advocating for users and meeting their needs within an organizational and societal context through the selection, creation, application, integration and administration of computing technologies." IT includes all facets of computing technology. (ACM/IEEE - IT2008, 2008)

An Information Technology curriculum should offer students appropriate knowledge and skills with the intention that upon graduation they are able to assume professional positions in Information Technology.

Specifically, the model asserts that within five years of graduation a student should be able to:

- "Explain and apply appropriate information technologies and employ appropriate methodologies to help an individual or organization achieve its goals and objectives;

- Function as a user advocate;

- Manage the information technology resources of an individual or organization;

- Anticipate the changing direction of information technology and evaluate and communicate the likely utility of new technologies to an individual or organization;

- Understand and, in some cases, contribute to the scientific, mathematical and theoretical foundations on which information technologies are built;

- Live and work as a contributing, well-rounded member of society." (The ACM/IEEE - IT Curriculum Model, 2008)

In addition, an IT graduate should have:

- "An ability to apply knowledge of computing and mathematics appropriate to the discipline

- An ability to analyze a problem, and identify and define the computing requirements appropriate to its solution 
- An ability to design, implement, and evaluate a computer-based system, process, component, or program to meet desired needs

- An ability to function effectively on teams to accomplish a common goal

- An understanding of professional, ethical, legal, security and social issues and responsibilities

- An ability to communicate effectively with a range of audiences

- An ability to analyze the local and global impact of computing on individuals, organizations, and society

- Recognition of the need for and an ability to engage in continuing professional development

- An ability to use current techniques, skills, and tools necessary for computing practice.

- An ability to use and apply current technical concepts and practices in the core information technologies.

- An ability to identify and analyze user needs and take them into account in the selection, creation, evaluation and administration of computer-based systems.

- An ability to effectively integrate IT-based solutions into the user environment.

- An understanding of best practices and standards and their application.

- An ability to assist in the creation of an effective project plan." (The ACM/IEEE - IT Curriculum Model, 2008)

The ACM/IEEE - IT Curriculum Model 2008 states that an IT curriculum consists of the body of knowledge and the general requirements. The body of knowledge is also referred to as the core knowledge. The core knowledge should be required of all IT students and it includes:

- ITF - Information Technology Fundamentals

- HCI - Human Computer Interaction

- IAS - Information Assurance and Security

- IM - Management

- IPT - Integrative Programming and Technologies

- MS - Math and Statistics for IT

- NET - Networking

- PF - Programming Fundamentals

- PT - Platform Technologies

- SA - Systems Administration and Maintenance

- SIA - System Integration \& Architecture

- SP - Social and Professional Issues

- WS - Web Systems and Technologies

The general requirements are knowledge and skills that go beyond the body of knowledge. They include:

- Knowledge of the scientific method - The IT graduate must possess the scientific method through "direct hands-on experience with hypothesis formulation, experimental design, hypothesis testing, and data analysis."

- Familiarity with application domains - IT students must be able "to work effectively with people from other disciplines."

- Communication skills - IT graduates "must be able to communicate effectively with colleagues and clients." 
- Teamwork skills - IT graduates must be able to work effectively in teams.

- Knowledge and skills of becoming a contributing member of society - IT graduates must have the appropriate skills to function effectively and cordially in society.

- Pervasive themes - IT graduates must "acquire a skill set that enables them to successfully perform integrative tasks, including user advocacy skills, the ability to address information assurance and security concerns, the ability to manage complexity through abstraction, extensive capabilities for problem solving across a range of integrated information and communication technologies, adaptability, outstanding interpersonal skills, high ethical standards, and professional responsibility." (The ACM/IEEE - IT Curriculum Model 2008)

The model also asserts that advanced courses may be included in the curriculum based on the "needs of students, the expertise of faculty members, and the needs of the wider community."

Finally, the ACM/IEEE - IT Curriculum Model 2008 encourages specialized accreditation, i.e., Accreditation Board for Engineering \& Technology - Computing Accreditation Commission (ABET - CAC) for IT programs that follow the ACM/IEEE - IT Curriculum Model.

\section{IT Program Design}

In this section we present a model that describes the design of an undergraduate IT program based on the ACM/IEEE - IT Curriculum Model recommendations. In addition, the model applies the ACM/IEEE - IT Curriculum Model's recommendations to design an IT program that produces IT versatilists. The model consists of two phases: designing the framework for the IT program and designing the courses in the curriculum. In presenting the model, examples from the undergraduate IT program at Macon States' School of Information Technology are used.

Macon State's School of Information Technology is a pioneer in offering the undergraduate degree program in Information Technology (IT). The IT program at Macon State's School of Information Technology was created in the late 1990s and produced its first IT graduates in 2000. The current program is based on the ACM/IEEE - IT Curriculum Model. It is the result of multiple revisions, which began in the early 2000s while ACM's SIGITE was working on the ACM/IEEE - IT Curriculum Model. Macon State's School of Information Technology was one of the 13 institution members of the IT 4-Year Curriculum Committee of the ACM's Computing Curricula, Information Technology Volume that later produced the ACM/IEEE - IT Curriculum Model in 2005 and the subsequent revision in 2008.

\section{Phase I - Designing the IT Program Framework}

Phase I of the IT program design includes designing the IT program framework that includes four components: program mission, program accreditation, program career goals, and program competencies. These components are essential criteria set aside by ABET - CAC for accrediting IT programs. Each component is a frame of reference for the succeeding components. The later components must be supported by the earlier components in order for this design phase to succeed.

\section{Formulating the program mission}

In formulating the mission, one must understand that the IT program guides the actions of the entity providing the program (e.g., a department of IT or a school of IT). The program mission must also be aligned with the overall mission of the institution. A sound program mission should clearly articulate the goals and directions. The mission should be a framework in which the program defines what it endeavors to provide. The following is the mission of the IT program at Macon State's School of Information Technology: 
The mission of the School of Information Technology is to educate students in information technology in ways that lead to fulfilling careers and enhance the economic vitality of Central Georgia. The School prepares its graduates to solve problems and apply new technologies within an increasingly interconnected and changing global environment. The School pursues this mission as an educational leader in teaching excellence, scholarship, professional service, and community outreach.

\section{Considering specialized accreditation for the IT program}

Once the mission is defined, consideration should be given to specialized program accreditation. Accreditation bodies have different goals. It is best to establish which accreditation program will be targeted before work is done on the specifics of the program. The ACM/IEEE - IT Curriculum Model 2008 supports the specialized accreditation of the Accreditation Board for Engineering \& Technology - Computing Accreditation Commission (ABET - CAC) for IT programs. Accreditation is important to all IT programs for a variety of reasons including the following:

- "Accreditation helps students and their parents choose quality college programs.

- Accreditation enables employers to recruit graduates they know are well-prepared.

- Accreditation is used by registration, licensure, and certification boards to screen applicants.

- Accreditation gives colleges and universities a structured mechanism to assess, evaluate, and improve the quality of their programs." (ABET, n.d. b)

Macon State's School of Information Technology chose to target the ABET-CAC, a nationally recognized and respected accreditation standard, for its IT program accreditation. This accreditation standard allowed flexibility to create a program that was aligned with the needs of its constituencies. It provided a framework for continuously improving the program.

\section{Establishing program career goals for graduates}

The third component in Phase one requires forward thinking across the entire career of IT graduates. It is hoped that IT graduates will have multi-year careers in IT. During that career a graduate may have a variety of job titles and responsibilities. The careers for which graduates are being prepared must be integral to the building of the IT program.

Specific careers should be identified based on the needs of constituents. The constituents include several groups of people with each group contributing differing insights.

Potential employers of the IT students are constituents. Here the following questions should be answered: What career opportunities do these employers offer? What job titles are found in these careers? What are the paths in these careers?

Students of IT are also constituents. The following questions regarding students must be answered: In what careers are the students capable of being successful? In what careers are students showing interest?

The regional community in which the IT program exists is also a constituent. Questions for this area that should be answered are: What industries currently exist in the community? What industries is the community capable of supporting?

In establishing the career goals, one must consider both job titles, job descriptions, and the skills and knowledge. It is best not to focus the career goals too specifically on job titles as job titles tend to be ambiguous. It is also best not to focus on very specific IT skills as IT skills tend to be transitory. Focusing on more general job descriptions is a more effective way to establish goals. 
An analysis should be done of job titles and descriptions with a goal of recognizing trends and similarities. Attention should also be paid to non-IT skills that support IT careers. These may include people skills, organizational skills, communication skills, and leadership skills.

ABET refers to the program career goals as the Program Educational Objectives. The ABET definition for Program Educational Objectives is "broad statements that describe the career and professional accomplishments that the program is preparing graduates to achieve." (ABET, n.d. a)

By ABET standards, Program Educational Objectives must be established. The Program Educational Objectives must be aligned with the mission of the program and the institution as whole. They must be based on the needs of the program's constituencies and, therefore, the program's constituencies must be identified as well. How those constituents' needs are determined must be documented. The Program Educational Objectives must be measurable. The methods to measure how well the objectives are being achieved must also be established and used to continuously improve the program.

The Program Educational Objectives at Macon State's School of Information Technology are aligned with the mission of the program and the institution. The mission of the Macon State is to offer "...baccalaureate degrees in areas linked directly to important regional needs in business, communications, information technology, nursing, teacher preparation, public service, health services administration and health information management." The IT program's constituencies, i.e., existing students, alumni, and the employers in the Central Georgia region, were an integral part of establishing a list of those regional needs. Specifically, the constituencies' input was obtained through the use of surveys administered to existing students, alumni, the regional employers, and the School's IT advisory board. The input from the IT program's constituencies is used to assess the achievement of the Program Educational Objectives and to continuously improve the program.

The IT Program Educational Objectives at Macon State's School of Information Technology requires that IT graduates, whom we refer to as IT "versatilists", should 1) assume productive roles in IT-related positions, and 2) pursue life-long learning enabling them to adapt and grow as organizational responsibilities change a few years after graduation.

\section{Establishing program competencies}

The last step in Phase I of designing an IT program includes the establishment of knowledge and skills that students should have by the time they complete the program. These are the competencies that students should have at the point of graduation. Establishing these competencies provides clear direction for working through the details of Phase II of the IT program design.

ABET requires a program to establish program competencies using the term "Program Outcomes". Program Outcomes are defined by ABET as follows:

"Narrower statements that describe what students are expected to know and be able to do by the time of graduation. These relate to skills, knowledge, and behaviors that students acquire in their matriculation through the program." (ABET, n.d. a)

These outcomes must be based on the needs of the program's constituencies and be measurable. Additionally, these outcomes must tie into the Program Educational Objectives. Lastly, the outcomes must be continuously improved using input from constituencies.

The IT program at Macon State's School of Information Technology has established a set of program outcomes. Input from the students, alumni, and area employers were used to initially establish these Program Outcomes. Table 1 shows these program outcomes mapped to the program educational objectives. 
Table 1: Macon State's School of Information Technology Program Outcomes Mapped to Educational Objectives

\begin{tabular}{|l|c|c|}
\hline \multicolumn{1}{|c|}{ IT Program Outcomes } & \multicolumn{2}{|c|}{$\begin{array}{c}\text { IT Program Educational } \\
\text { Objectives }\end{array}$} \\
\cline { 2 - 3 } & $\mathrm{A}$ & $\mathrm{B}$ \\
\hline Demonstrate expertise in the core information technologies & $\mathrm{x}$ & \\
\hline $\begin{array}{l}\text { Demonstrate the ability to analyze, identify, and define informa- } \\
\text { tion system requirements }\end{array}$ & $\mathrm{x}$ & \\
\hline $\begin{array}{l}\text { Design and implement effective and usable IT-based solutions in } \\
\text { a user environment }\end{array}$ & $\mathrm{x}$ & \\
\hline $\begin{array}{l}\text { Use appropriate project management methods in the creation of } \\
\text { an effective IT project plan }\end{array}$ & $\mathrm{x}$ & \\
\hline $\begin{array}{l}\text { Identify IT methods used in protecting the confidentiality, integ- } \\
\text { rity, and availability of information and its delivery systems }\end{array}$ & $\mathrm{x}$ & $\mathrm{x}$ \\
\hline Identify and apply current and emerging technologies & $\mathrm{x}$ & \\
\hline $\begin{array}{l}\text { Apply relevant ethical, legal, security, and policy principles in } \\
\text { technology environment }\end{array}$ & $\mathrm{x}$ & $\mathrm{x}$ \\
\hline $\begin{array}{l}\text { Describe and apply best practices and standards in IT applica- } \\
\text { tions }\end{array}$ & $\mathrm{x}$ & $\mathrm{x}$ \\
\hline $\begin{array}{l}\text { Demonstrate independent critical thinking and problems solving } \\
\text { skills }\end{array}$ & $\mathrm{x}$ & $\mathrm{x}$ \\
\hline $\begin{array}{l}\text { Work effectively in teams to develop IT based solutions } \\
\text { Communicate effectively }\end{array}$ & $\mathrm{x}$ & \\
\hline $\begin{array}{l}\text { Recognize the need for lifelong professional development and } \\
\text { learning }\end{array}$ & & \\
\hline Assing & \\
\hline
\end{tabular}

A. Assume productive roles in IT-related positions.

B. Pursue life-long learning enabling them to adapt and grow as organizational responsibilities change.

At Macon State's School of Information Technology, direct and indirect assessment methods are used to continuously improve these outcomes and to measure whether they are being achieved.

Indirect assessment of these outcomes is achieved using the following:

- Current student survey - administered every three years

- Alumni survey - administered every three years

- Graduating student survey - administered every semester

In addition, the School of Information Technology advisory board's recommendations are taken into consideration for indirect assessment of the program outcomes. Finally, an integral part of the senior capstone course within the curriculum is used to indirectly assess the program outcomes. The senior capstone course is taught every semester.

The direct assessment of these program outcomes is accomplished via courses within the core knowledge area. To facilitate the direct assessment at Macon State's School of Information Technology, the outcomes were divided into three groups of four. One of these groups is assessed in selected core courses each year. This schedule provides for the entire group to be assessed every three years. 


\section{Phase II - Designing Courses}

Phase II of the IT program design begins once the mission, the educational objectives, and the program outcomes are in place. In this Phase the specific courses are established. These courses should support the foundational work of Phase I.

In addition, the courses in the curriculum are designed to produce graduates that are IT versatilists. As mentioned earlier, IT versatilists possess a depth of knowledge combined with an understanding beyond one specialized area. IT versatilists recognize other domains within organizations and understand various aspects of IT as well as how their specialized area fits into IT as a whole.

In designing Phase II to produce IT versatilists, we include the following:

1. Designing the IT foundational courses

2. Designing the advanced IT courses

Both the IT foundational courses and the advanced IT courses are built around the body of knowledge and the general requirements as recommended by the ACM/IEEE - IT Curriculum Model 2008. The IT foundational courses consists of a group of courses that all IT students are required to take.

The advanced IT courses included to address the ACM/IEEE - IT Curriculum Model's recommendation. Advanced courses go "beyond the boundaries of the core and ...provide depth in the curriculum" (ACM/IEEE - IT2008, 2008). The advanced IT courses are divided into two groups; concentrations specific to IT and informatics.

\section{Designing the IT Foundational Courses}

As described earlier, ACM/IEEE IT Curriculum Model recommends specific knowledge areas that make up the body of knowledge necessary for a strong IT program. The foundational IT courses at Macon State were designed around the above set of knowledge areas. Table 2 shows Macon State's IT foundational courses and how they are mapped to the ACM/IEEE - IT Curriculum Model's recommendations. 
Table 2: A Comparison of Macon State's IT Foundational Courses with the ACM/IEEE - IT Curriculum Model's Knowledge Areas

\begin{tabular}{|l|l|}
\hline $\begin{array}{l}\text { Macon State's School of Information Tech- } \\
\text { nology - IT Foundational Courses }\end{array}$ & $\begin{array}{l}\text { ACM/IEEE - IT Curriculum Model 2008 - } \\
\text { Knowledge Areas }\end{array}$ \\
\hline Introduction to Information Technology & ITF \\
\hline Computer Programming & PF \\
\hline Application Development & PF \\
\hline Networking Essentials & NET, PT \\
\hline Web Development & WS \\
\hline Statistical Methods & MS \\
\hline Systems Analysis and Design & SIA, SP \\
\hline Human Computer Interaction & HCI \\
\hline Interactive Digital Media & WS \\
\hline Database Principles & IM \\
\hline Data Driven Web Development & WS, IPT, SA \\
\hline Project Management & SIA, SP \\
\hline Integrating Information Technologies & SP, SIA, ITF \\
\hline Decision Support \& Organizational Intelligence & IM, SP \\
\hline Foundations of Information Assurance & IAS \\
\hline
\end{tabular}

ITF Information Technology Fundamentals, HCI Human Computer Interaction, IAS Information Assurance and Security, IM Information Management, IPT Integrative Programming and Technologies, MS Math and Statistics for IT, NET Networking, PF Programming Fundamentals, PT Platform Technologies, SA Systems Administration and Maintenance, SIA System Integration \& Architecture, SP Social and Professional Issues, WS Web Systems and Technologies

Likewise, the ACM/IEEE - IT Curriculum Model includes a set of general requirements. These general requirements were used as a framework for Macon State's IT foundational courses. Table 3 maps the general requirements to these foundational courses.

Table 3: ACM/IEEE - Macon State's IT Foundational Courses mapped IT Curriculum Model's General Requirements' Recommendations

\begin{tabular}{|c|c|c|c|c|c|c|}
\hline Macon State's Foundational Courses & 1 & 2 & 3 & 4 & 5 & 6 \\
\hline Introduction to Information Technology & & $\mathrm{x}$ & $\mathrm{x}$ & & $\mathrm{x}$ & $\mathrm{x}$ \\
\hline Introduction to Computer Programming & $\mathrm{x}$ & $\mathrm{x}$ & $\mathrm{x}$ & & & $\mathrm{x}$ \\
\hline Application Development & $\mathrm{x}$ & & $\mathrm{x}$ & & & $\mathrm{x}$ \\
\hline Networking Essentials & $\mathrm{x}$ & & $\mathrm{x}$ & & & $\mathrm{x}$ \\
\hline Web Development & & & $\mathrm{x}$ & & & $\mathrm{x}$ \\
\hline Statistical Methods & $\mathrm{x}$ & & $\mathrm{x}$ & & & \\
\hline Systems Analysis and Design & & $\mathrm{x}$ & $\mathrm{x}$ & $\mathrm{x}$ & $\mathrm{x}$ & \\
\hline Human Computer Interaction & & & $\mathrm{x}$ & $\mathrm{x}$ & $\mathrm{x}$ & $\mathrm{x}$ \\
\hline Interactive Digital Media & & & $\mathrm{x}$ & & & $\mathrm{X}$ \\
\hline Database Principles & & & $\mathrm{x}$ & & & $\mathrm{x}$ \\
\hline Data Driven Web Development & & & $\mathrm{x}$ & & & $\mathrm{x}$ \\
\hline Project Management & & $\mathrm{x}$ & $\mathrm{x}$ & $\mathrm{x}$ & & $\mathrm{x}$ \\
\hline Integrating Information Technologies & $\mathrm{x}$ & $\mathrm{x}$ & $\mathrm{x}$ & $\mathrm{x}$ & $\mathrm{x}$ & $\mathrm{x}$ \\
\hline $\begin{array}{l}\text { Decision Support \& Organizational Intelli- } \\
\text { gence }\end{array}$ & $\mathrm{x}$ & & $\mathrm{x}$ & & $\mathrm{x}$ & $\mathrm{x}$ \\
\hline Foundations of Information Assurance & & & $\mathrm{x}$ & & & $\mathrm{X}$ \\
\hline Senior Capstone & $\mathrm{x}$ & $\mathrm{x}$ & $\mathrm{x}$ & $\mathrm{x}$ & $\mathrm{x}$ & $\mathrm{x}$ \\
\hline
\end{tabular}

1. Knowledge of the scientific method; 2. Familiarity with application domain; 3. Communication skill; 4. Teamwork skill; 5. Knowledge and skills of becoming a contributing member of society; 6. Pervasive themes 
The foundational courses also take into consideration the requirements of the chosen accrediting body from Phase I. For example, ABET accreditation requires the following: The core information technologies of human computer interaction, information management, programming, networking, web systems and technologies, information assurance and security. These are addressed in the School of Information Technology's foundational courses as shown in Table 4.

Table 4: ABET Required Area mapped to Macon State's IT Foundational Courses

\begin{tabular}{|l|l|}
\hline Required Area by ABET & IT Foundational Courses at Macon State \\
\hline Human computer interaction & $\begin{array}{l}\text { Human computer Interaction } \\
\text { Systems Analysis }\end{array}$ \\
\hline Information management & $\begin{array}{l}\text { Database Principles } \\
\text { Interactive Digital Media } \\
\text { Foundations of Information Assurance } \\
\text { Decision Support Systems }\end{array}$ \\
\hline Programming & $\begin{array}{l}\text { Introduction to Computer Programming } \\
\text { Applications Development }\end{array}$ \\
\hline Networking & Networking Essentials \\
\hline Web systems and technologies & $\begin{array}{l}\text { Web Development } \\
\text { Data Driven Web Development }\end{array}$ \\
\hline
\end{tabular}

The Senior Capstone is a critical, final element in the IT foundational course work at Macon State. The capstone supports the suggested integrated capstone experience in the description of the Core Curriculum in the ACM/IEEE - IT2008 model. The senior capstone course requires students (normally in teams of four to six members) to integrate their skills and knowledge they have acquired throughout the IT program to analyze, design, develop, implement, and assess an information system. The course projects in this course are real-world, hands-on, and experiential. They involve real clients or sponsors. The course also requires students to produce self-assessment document in two parts. Part 1 includes student's reflection upon the knowledge and skills he or she has acquired throughout the IT program. Part 2 consists of evaluating the IT program as to how well they achieved each of the program outcomes and how important each program outcome is in relation to their learning. The self-assessment feedback is used to indirectly assess the IT program for continuous improvement.

\section{Designing the Advanced Courses in IT Curriculum}

Advanced coursework is an important contribution to the versatility of IT graduates. They offer depth to the curriculum that goes beyond merely the foundational courses. The advanced courses offer IT versatilists a diversified set of skills and experiences to fulfill multiple roles within organizations.

Macon State's advanced IT curriculum consists of two alternatives: IT concentrations and Informatics concentrations. The general requirements knowledge and the IT core knowledge are integrated into both IT concentrations and informatics concentrations. The advanced IT course-work, however, differs somewhat depending on the direction chosen.

\section{Advanced courses - IT concentrations}

The ACM/IEEE - IT Curriculum Model recommends that advanced courses be included within an IT Curriculum. At Macon State's School of Information Technology, students have the option to take one or two major concentrations. The IT concentrations allow the student to obtain more in depth knowledge of several specific areas found in the core requirements. The IT concentrations within the curriculum are as follows: 
Network Technologies \& Administration (Courses offered in this concentrations are: Windows System Administration, Web Server Administration, Forensics/Data Recovery, Wireless Technologies, Data Communications, Network Security)

Information Assurance \& Security (Courses offered in this concentrations are: Legal and Ethical Issues in IT, Web Server Administration, Forensics / Data Recovery, Database Security and Disaster Recovery, Network Security, Software Security)

Integrated Digital Media (Courses offered in this concentrations are: Graphic Imaging, Desktop Publishing \& Graphic Design, Digital Video \& Streaming Media, 2D Computer Animation, Web Application Development, Designing Content for Technology Applications)

Software Development (Courses offered in this concentrations are: Database Administration, Structured Query Language, Integrating Enterprise Systems, C/C++ Programming, COBOL, Web Applications Development, Software Security)

Information Technology Management (Courses offered in this concentrations are: Business Analysis Using Excel, Legal and Ethical Issues in Information Technology, Integrating Enterprise Systems, Business Driven Technology, Electronic Commerce Systems, Globalization and Technology)

In order for a student to receive an IT concentration at Macon State's School of Information Technology, he or she must take 15 hours of advanced coursework that focuses on his/her chosen concentration. Several of these concentrations align directly with the knowledge areas described in the ACM/IEEE - IT2008 model.

\section{Advanced courses - Informatics concentrations}

Informatics experience can help IT versatilists to perform several roles within organizations. For example, an IT versatilist with skills in health informatics will gain cross-organizational awareness. This awareness together with technical aptitude and soft skills enable an IT versatilist to perform multiple roles, thus contributing to the vitality of the organization.

Macon State's School of Information Technology goes beyond the standard IT advanced courses and offers informatics concentrations. Informatics is the bridge that connects IT to other areas of study. Informatics provides students with a strong foundation in IT as well as a deeper understanding of another discipline. Informatics allows graduates to more rapidly develop IT solutions for organizations within specific domains.

Currently the School of Information Technology offers the following informatics concentrations: business informatics, health informatics, mathematics informatics, English informatics, humanities informatics, biology informatics, and history informatics. A student pursuing an Informatics Concentration is required to complete the IT foundational courses, 15 hours of advanced IT courses, and 15 hours of courses within the chosen informatics concentration. For example, a BS in IT with a concentration in mathematics requires the IT foundational courses, 15 hours of advanced IT courses, and 15 hours of mathematics courses taught by the Department of Mathematics. Students pursuing an informatics concentration complete the coursework that was framed around both the ACM/IEEE - IT Curriculum Model and ABET requirements; however, informatics students will have a stronger understanding of a particular application domain. 


\section{Conclusion}

This paper presented a model for designing an undergraduate IT program that produces IT versatilists. Macon State's School of Information Technology has designed its IT program around this model. The model is based on the recommendations made by the ACM/IEEE - IT Curriculum Model. The model includes two phases - the IT program framework and the design of IT courses.

The IT program framework consists of four essential elements: 1) the formulation of the program mission, 2) the consideration of the program accreditation, 3) the establishment of the program career goals, and 4) establishment of the program competencies. Each component has its own unique elements that are essential to the design of any IT program. This Phase takes into considerate the criteria set aside by ABET - CAC for accrediting IT programs. The completion of this Phase ensure the quality standards for the IT program as confirmed by ABET-CAC.

Phase II of the model includes designing the courses for the curriculum. This Phase involves planning the IT foundational courses and the advanced IT courses around the body of knowledge and the general requirements as recommended by the ACM/IEEE - IT Curriculum Model. The IT foundational courses are required courses within the curriculum. The advanced IT courses go beyond the foundational courses to provide additional strength within the curriculum. The advanced IT courses consist of the IT concentrations and the informatics concentrations. The IT concentrations are network technologies $\&$ administration, information assurance $\&$ security, integrated digital media, software development, and information technology management. Informatics concentrations are courses that are taken beyond the IT discipline. They are business informatics, health informatics, mathematics informatics, English informatics, humanities informatics, biology informatics, and history informatics.

We believe that the ACM/IEEE - IT Curriculum Model is the backbone of any undergraduate IT program design. Our model has taken these recommendations into consideration in order to advance an IT program that embraces the vital components of an undergraduate IT program, i.e., the core knowledge, the general requirements beyond the core, and the advanced courses, which contribute to producing graduates that are IT versatilists. In addition, the model ensures the quality standards of the curriculum by adopting the program accreditation standards of ABET. We recommend the use of this model in designing undergraduate IT programs.

\section{References}

ABET. (n.d. a). Glossary. Retrieved from http://www.abet.org/TrainingCD/data/Glossary/glossary.htm

ABET. (n.d. b). Why should my program seek accreditation? Retrieved from http://www.abet.org/why_seek.shtml

ACM/IEEE - IT 2008. (2008). Information technology undergraduate curriculum model. Association for Computing Machinery. Retrieved October 18, 2009 from http://www.acm.org/education/curricula/ACM/IEEE - IT2008\%20Curriculum.pdf

Annabi, H., \& McGann, S. (2008). Preparing the knowledge worker: How can IS programs meet the challenge? Issues in Information Systems, 9(1), 196-202.

Brewer, J., Harriger, A., \& Mendonca, J. (2006). Beyond the model: Building an effective and dynamic IT curriculum. Journal of Information Technology Education, 5, 441-458. Retrieved from http://www.jite.org/documents/Vol5/v5p441-458Brewer149.pdf

Downey, J. P., McMurtrey, M. E., \& Zeltmann, S. M. (2008). Mapping the MIS curriculum based on critical skills of new graduates: An empirical examination of IT professionals. Journal of Information Systems Education, 19(3), 351-363. 
Drinka, D., \& Yen, M. Y. (2008). Controlling curriculum redesign with a process improvement model. Journal of Information Systems Education, 19(3), 331-342.

Morello. D. (2005). The IT Professional Outlook: Where Will We Go From Here? Gartner, Inc.

Lunt, B. M., Lawson, E. A., Goodman, G., \& Helps, C. R. G. (2002). Designing an IT curriculum: The results of the first CITC conference. Proceedings of the 2002 American Society for Engineering Education Annual Conference \& Exposition. Montreal, Quebec, Canada.

Woratschek, C. R., \& Lenox, T. L. (2009). Defining CS, IS, and IT: Are we there yet? Information Systems Education Journal, 7(59), 1-30.

\section{Biographies}

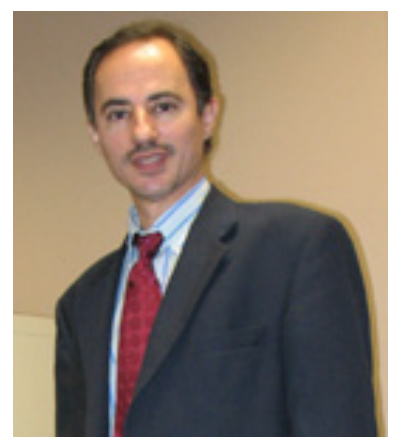

Alex Koohang is Peyton Anderson Eminent Scholar and Professor of Information Technology in the School of Information Technology at Macon State College. He is also the Dean of the School of Information Technology at Macon State College. Dr. Koohang has been involved in the development of online education, having initiated and administered some of the earliest asynchronous learning networks. His current research interests are in the areas of e-learning, learning objects, open education, and curriculum design.

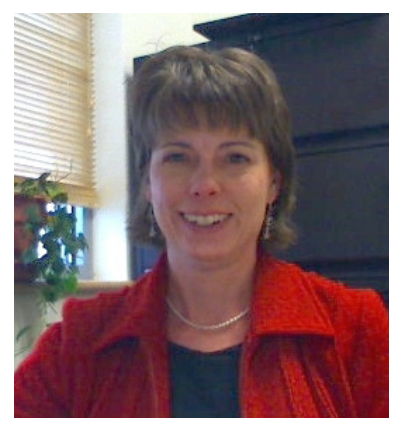

Elizabeth Riley is an Associate Professor in the School of Information Technology at Macon State College. She holds a M.B.A. from Georgia College and State University. She has 15 years experience as an Information Technology professional and has taught programming and web design courses for the last six years. She has an interest in the educational opportunities offered by virtual worlds.

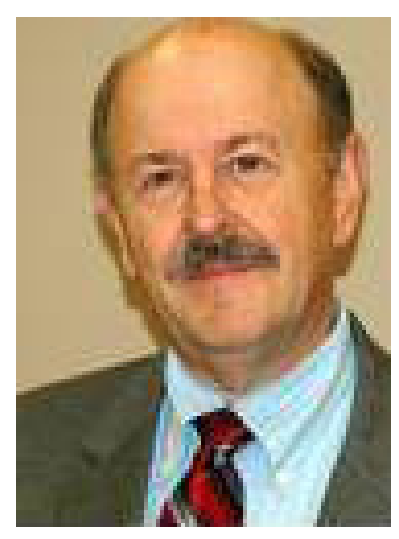

Terry Smith is an assistant professor in the School of Information Technology at Macon State College in Macon, Georgia. He holds a M.B.A. from the University of South Florida in Tampa, Florida, and a $\mathrm{Ph} . \mathrm{D}$. in Information Systems from Nova Southeastern University in Ft. Lauderdale, Florida. His research interests include human computer interaction, Web and Internet technologies, E-business, Ecommerce, and E-government. 


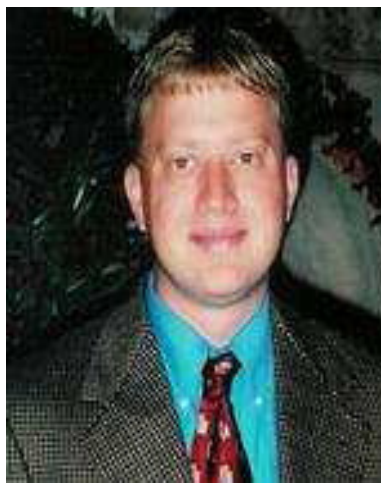

Kevin Floyd is assistant professor of Information Technology in the School of Information Technology at Macon State College. He teaches in the areas of programming \& application development, information security, and IT integration. His current research interests are in the areas of open source, accessibility, and information security. 